\title{
ユーザビリティの評価
}

\section{早川 誠二*}

ここで解説する、ユーザビリティ評洒とは、ユーザ 一が製品の持つさまざまな機能をスムーズにしかも快 適に利用できるかどうかを検証し、製品仕様の問題点 を抽出する活動である。

本章では、ユーザビリティの評価に関して、その考 え方や具体的な方法について述べる。

ユーザビリティ評価にはさまざまな手法があるが、 ここではモニターューザー（実験協力者、以下モニタ ーと呼ぶ）を活用したユーザビリティテスティングを 中心に解説する。

\section{1.ユーザビリティ評価と人間中心設計プロセス \\ 1.1 ユーザビリティの定義}

ユーザビリティと言う言葉は最近では一般的になっ てきているが、旧来の JISでは「使用性」と訳されて おり、日本語としては「使い勝手」や「使いやすさ」 という表現が一般的である。

ISO9241によれば、「特定の作業環境における作業シ ナリオにもとづいて、特定の作業を遂行するために、 特定のトレーニングとユーザーサポートを与えられた、 特定のユーザーが容易にかつ効果的に利用できるとい う機能的な側面からみた可能性」と定義されている。 したがって、製品を使用するユーザーの特性や環境な どそれぞれの状況に大きく依存する。ユーザビリティ では一つの正解が存在するのではなく、それぞれの状 況に応じた最適解を求めることになる。

ユーザビリティの指標は、「効果性(Effectiveness)」、 「効率性 (Efficiency)」「満足度 (Satisfaction)」で表 される。

一方、ヤコブ・ニールセンは、図 1 に示すようにシ ステムの受容性の中でューザビリティを定義しており、 ユーザビリティは学習のしやすさ、使いやすさ、記憶 しやすさ、エラーの少なさ、主観的満足度の 5 つの特 性を持つとしている。

これらはISO と同様に多面的な構成要素に分解する

$\dagger$ Usability Evaluation Seiji HAYAKAWA

* 株式会社リコー 経営品質管理本部 アプライアンス推進室 Appliance Promotion Office Quality of Management Division RICOH COMPANY, LTD.
ことで、ユーザビリティという抽象的なコンセプトを 測定可能にしている。ここでは、ユーザビリティと実 用性（Utility）を合わせた有用性(Usefulness)を広義 のユーザビリティと捉えている。これは、ユーザビリ ティは単独で存在するわけでなく、あくまで特定の機 能についての使いやすさであるという考え方から来て いる。

\subsection{ISO13407とユーザビリティ}

1999年にISO13407として制定され、翌年 JISZ8530に なった「インタラクティブシステムにおける人間中心 設計プロセス (Human Centred Design Process for Interactive Systems)」という規格がある。この規格は、 ISO9000と同様なプロセス規格であり、特定の数值を示 した規格ではなく、「ユーザーをサポートし、学習意欲 を持たせ、生産性の向上・作業品質の向上、サポート・

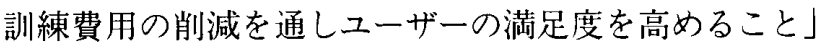
をめざした国際規格である。対話型システム設計にあ たって人間要素および人間工学を考慮することで

一 有効性・効率性が高まり

一 人間の作業条件が改善され

一 健康や安全、能率への悪影響を抑止できる としている。この規格では、ユーザビリティの高い製 品を作るための諸活動を規定しており、网 2 のような 設計プロセスで製品を作るべきとしている。この設計 プロセスでの評価（ユーザビリティ評価）では、ユー ザーや組織の要求に対して設計解決案が満足している かどうかを評価する。単純に使いやすいか使いにくい かと言った使い勝手評価ではない。また、ユーザビリ ティ評価を含むこのサイクルは製品開発の特定のステ ップで適用されるものではなく、企画、開発、設計、 製造、さらには販売、サービスといったそれぞれのス テップで実施されるものとしている。

\section{2. ユーザビリティ評価における方法と手法}

\section{1 評価対象}

ユーザビリティ評価は、製品開発プロセスの中では、 技術的な試作機やデザインプロトタイプ（ペーパープ ロトタイプも含む）などを用いて行う。もちろん、市 場に出てからの商品（競合する製品も含め）を対象に 


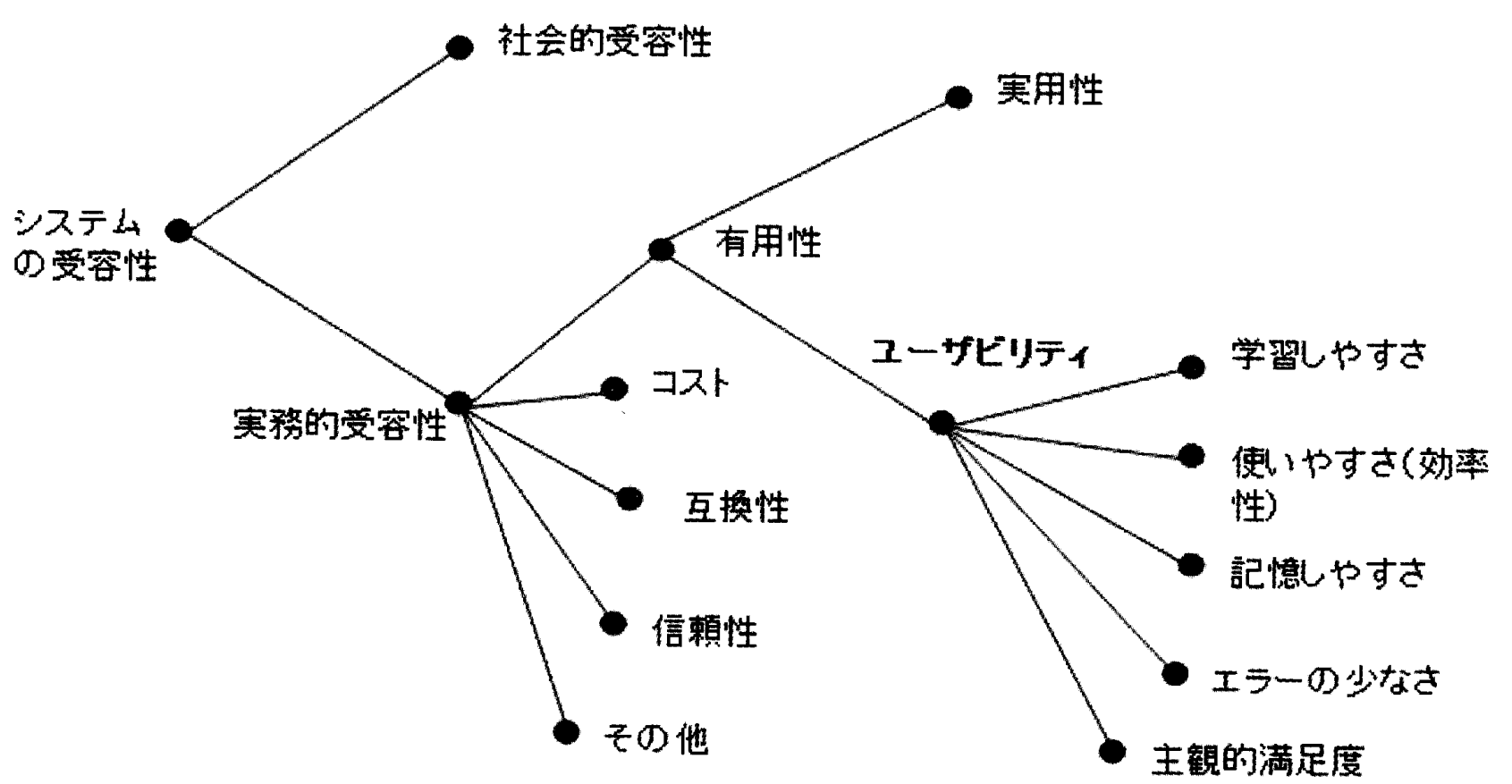

図 1 システムの受容性の構成（ヤコブ・ニールセン）

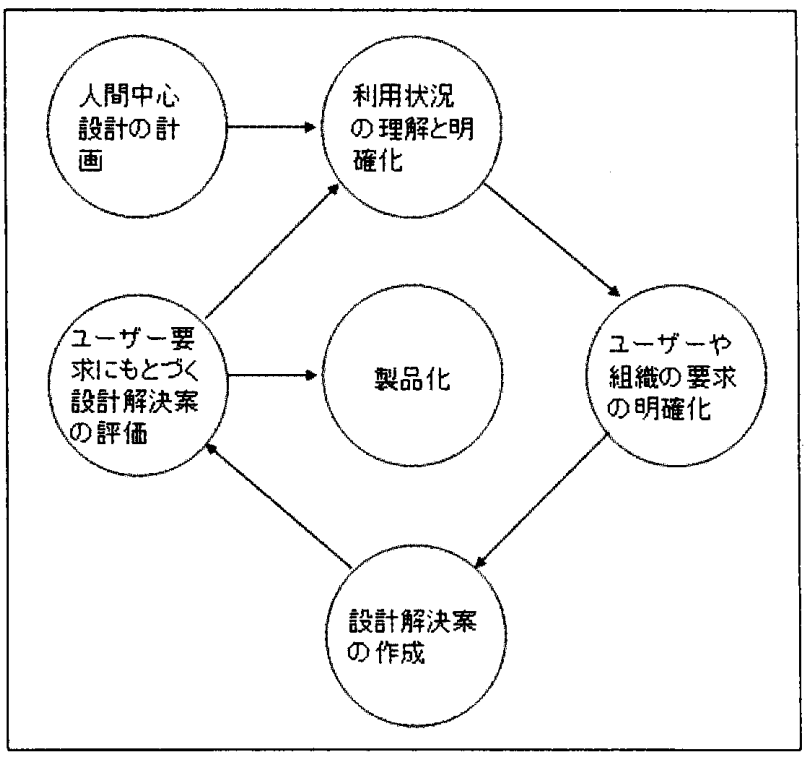

図 2 人間中心設計プロセス

評価することもある。

\section{2 評価目的}

ユーザビリティ評価の目的は、大きく分けると以下 のように分類できる。

- 改善案の抽出

対象とするユーザーがその製品を使用したときに、ど のような問題点があるのかを発見し、その原因を究明
することによって、プロトタイプや試作機（設計解決 案）をどのように改善したらよいかを検討するための 評価である。もっとも一般的な評価である。

一 水準の決定

例えば、操作パネルの床面からの高さなど、対象とす るユーザーにとって、その製品がどのような水準にあ れば使いやすいかを検討するための評価である。この 評洒においては、製品の要素(操作パネルの高さなど) を変化させた実験機などを用意して行う。

- レベルの判定

例えば、競合製品と比べその製品のユーザビリテイが どの程度のレべルにあるのかを判定するための評価で ある。評洒結果は、数値化して比較しやすいよう表す ことが多い。

\section{3 ユーザビリティ評価の方法}

ユーザビリティ評洒は大きく分け、ユーザー（モニ ター、被験者）を使う方法と使わない方法がある。

ユーザーを使うユーザビリティ評価はさらに、

一 達成時間やエラー率など効率を評価・測定するパ フォーマンス評価

一 質問紙やインタビューなどューザーの主観を評価 する主観評価

一 実際に課題を与え、製品を操作してもらい評洒す 
るユーザビリティテスティング

に分類できる。

ユーザーを使う評価手法としてのユーザビリティテ スティングでは、プロトコル分析 (発話思考法) や観 察法がよく使われる。プロトコル分析は、ユーザーの 操作（課題遂行）過程における発話データをすべて書 き起こし、ユーザーの行動とともに分析するとなると 相当な負荷がかかることから、メーカーではユーザー の発話をすべて書き起こさない簡易的な方法を取るこ とが多い。

ユーザビリティテスティングのメリットは、ユーザ 一の実際の思考過程を簡易的に知ることができるとと もに、実際に観察することにより、設計者やデザイナ 一の改善に対する意識付けがしやすいことにある。

一方、ユーザビリティテスティングの進行者は訓練 を積まないとできないことや、どうしても発話しなが らの操作の状況が不自然になるという課題もある。

ユーザーを使わないユーザビリティ評価方法は、イ ンスペクション法とも呼ばれ、ユーザビリティ検查者 が行う評価である。この方法の代表例として、

一チェックリストによる評価

メリット：ユーザビリティの原則などを十分理解し
ていなくとも評価できる、効率的である。

デメリット：チェックリストに載っている範囲でし か評価できない、チェックリストの維持管理が必要で ある。

図 3 に OA 機器におけるチェックリストの例を示す。

一ヒューリスティック (発見)による評価 メリット：個々のユーザビリティの問題が発見でき

る。熟練（経験者）ユーザーの問題も扱える。

デメリット：検査者としてスキルが必要である。

以下に例としてヤコブ・ニールセンによるヒューリ スティック評価における原則を示す。

1.シンプルで自然な対話を実現する

2.ユユーザーの言葉で話す

3.ユーザーの記憶負荷を最小限にする

4.一貫性を保つ

5 。適切なフィードバックを与える

6. 出口を明らかにする

7.ショートカットを用意する

8. 適切なエラーメッセージを返す

9.エラーを防ぐ

10. 適切なへルプとドキュメンテーションを用意する それぞれの原則にもとづき、どのような観点で問題

\begin{tabular}{|c|c|c|c|c|c|c|c|c|}
\hline \multirow{2}{*}{ 唡话 } & \multirow[t]{2}{*}{2014} & \multicolumn{4}{|c|}{ 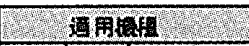 } & \multirow{2}{*}{\multicolumn{2}{|c|}{ 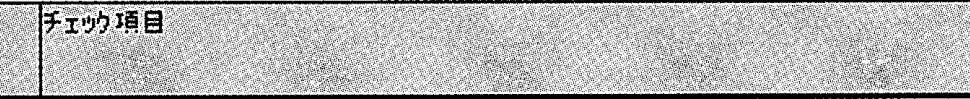 }} & \multirow{2}{*}{$\begin{array}{l}\text { 使用 } \\
\text { 用旦 }\end{array}$} \\
\hline & & $P p$ & $2=$ & rax & Afre & & & \\
\hline & 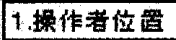 & 0 & 0 & 0 & O & 1 & 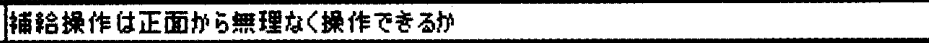 & \\
\hline & 2.用斩辅辁 & 0 & 0 & 0 & 0 & 1 & 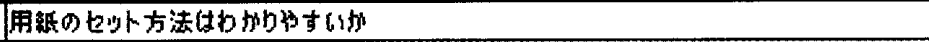 & \\
\hline & 本体 & 0 & 0 & 0 & 0 & 2 & 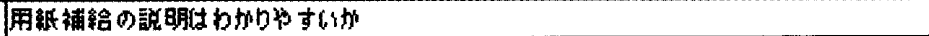 & \\
\hline & & $\bar{O}$ & 0 & 0 & o & 3 & 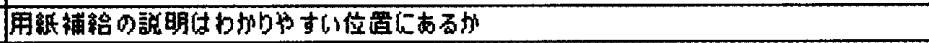 & \\
\hline & & 0 & $\Delta$ & $\Delta$ & 0 & 4 & 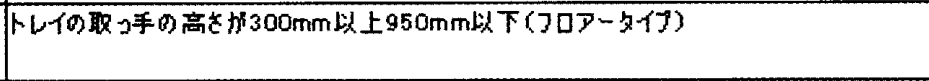 & 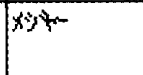 \\
\hline & & 0 & 0 & 0 & 0 & 5 & トレイの取っ手はー目で、それとりかるか & \\
\hline & & 0 & 0 & 0 & 0 & 6 & |トレイの取っ手の指が加り通切か & \\
\hline & & 0 & 0 & 0 & 0 & 7 & 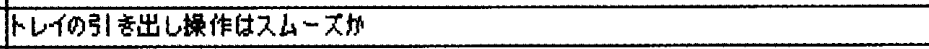 & \\
\hline & & 0 & 0 & $a$ & 0 & 8 & 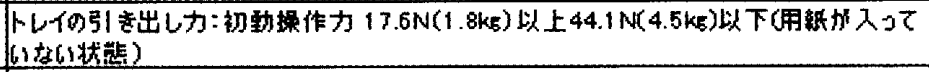 & $\bar{\top} ソ タ ョ ソ ケ^{2}-y^{2}$ \\
\hline & & 0 & 0 & 0 & 0 & 9 & 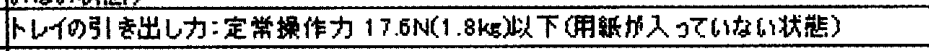 & $\overline{\left.\mathrm{T} Y y_{9}\right) V^{*}-y^{*}}$ \\
\hline & & 0 & 0 & 0 & $\mathrm{O}$ & 10 & 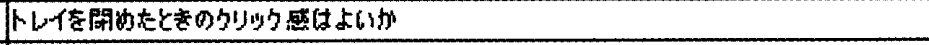 & \\
\hline & & 0 & 0 & 0 & 0 & 11 & 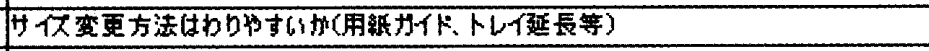 & \\
\hline & & 0 & 0 & 0 & 0 & 12 & 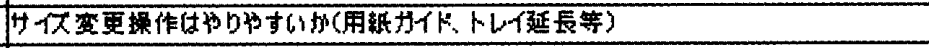 & \\
\hline & & 0 & 0 & 0 & 0 & 13 & 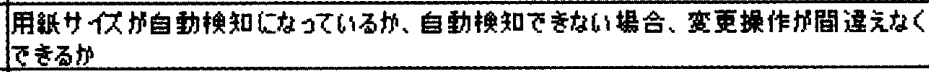 & \\
\hline & & 0 & 0 & 0 & 0 & 14 & 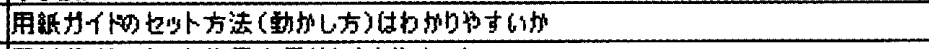 & \\
\hline & & 0 & 0 & 0 & 0 & 15 & 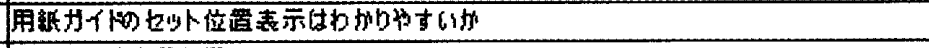 & \\
\hline & & 0 & 0 & 0 & 0 & 16 & 用敏サ仅表示《晃 & \\
\hline & & 0 & 0 & 0 & 0 & 17 & 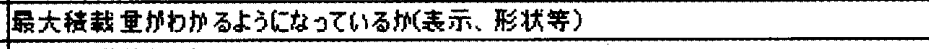 & \\
\hline & & 0 & 0 & 0 & 0 & 18 & 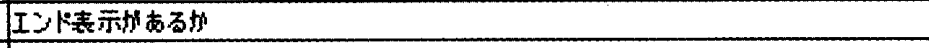 & \\
\hline & & 0 & 0 & 0 & 0 & 19 & 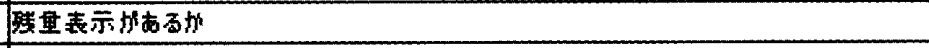 & \\
\hline & & 0 & 0 & 0 & 0 & 20 & 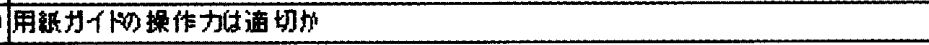 & \\
\hline & & 0 & 0 & 0 & 0 & 21 & 用新のセ少トはスムースに行えるか & \\
\hline & & 0 & 0 & 0 & 0 & 22 & 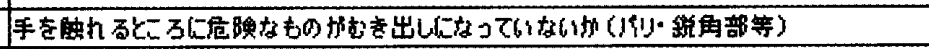 & \\
\hline
\end{tabular}

図 3 操作性チェックリストの例 


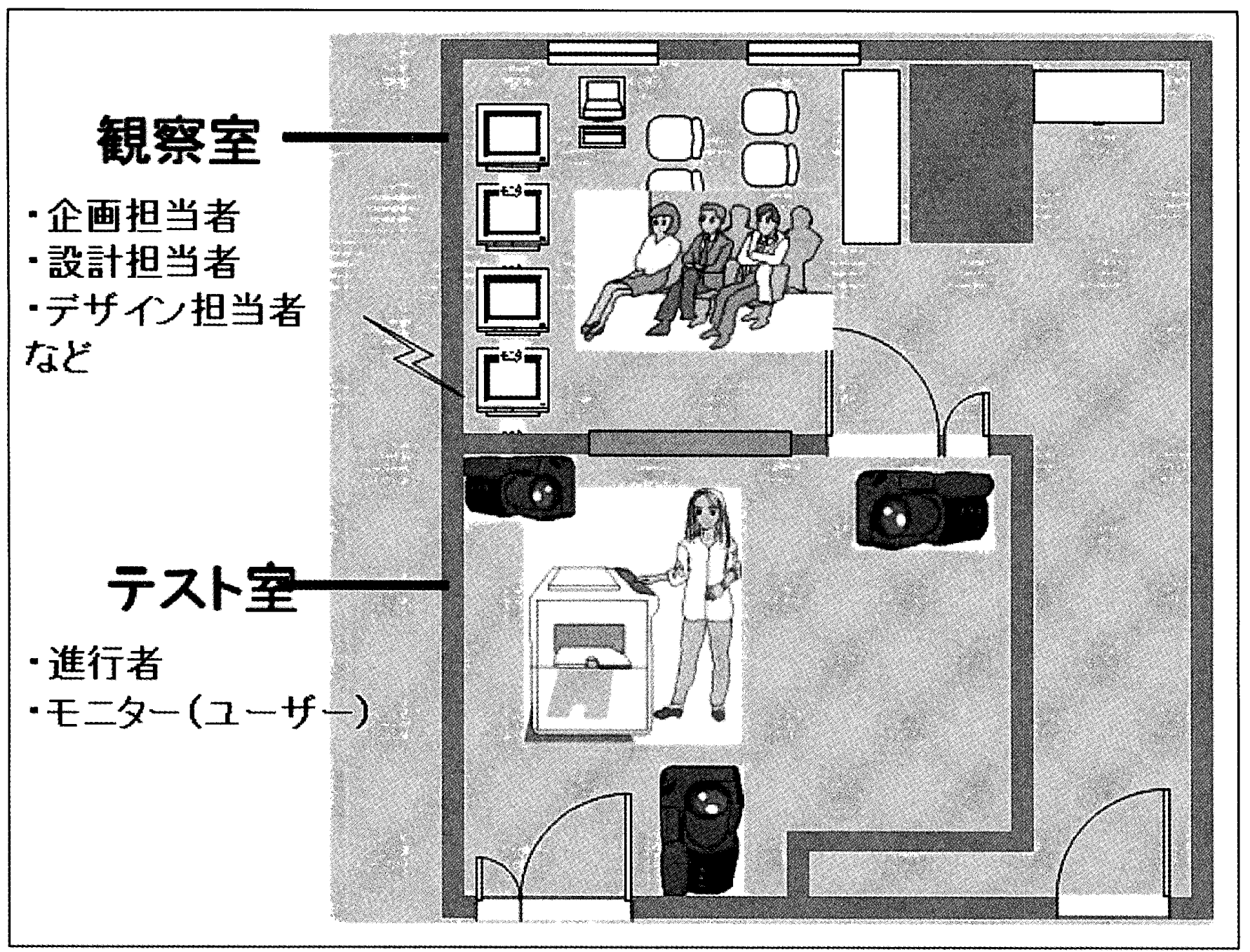

図4 ユーザビリティテストラボレイアウト例

を発見するかが文献には示されている。

\section{3. ユーザビリティ評価の実際}

ユーザーを活用したユーザビリティ評価の代表的な 方法であるユーザビリティテスティングに関してその 実際を紹介する。

\section{1 評価の環境}

ユーザビリティテスティングの環境として、一般的 にユーザビリティテストラボと呼ばれる専門の設備を 用意しているところが多い。最近では、数十の会社で テストラボを用意して評価を行っている。ユーザビリ ティテストラボは図 4 に示すよjに、テスト室と観察 室に分かれており、観察室からはマジックミラー越し にユーザーの行動、発話を観察できる。観察室にはテ スト室での進行を観察、記録するオーディオ、ビデオ の設備があり、ユーザビリテイ評価を担当するものだ けでなく、設計者やデザイナーなどが同時に観察する ことが多い。(図 5 )

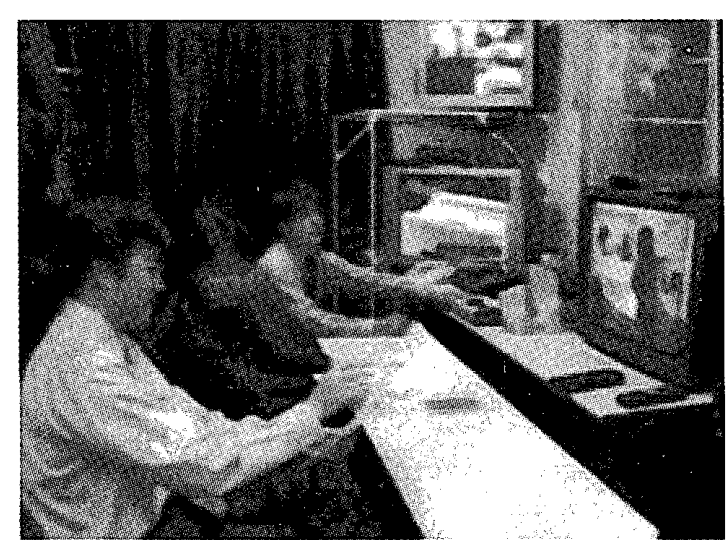

図 5 ユーザビリティテストラボ観察室風景

テストラボがない場合、会議室などの一角を仕切り、 ビデオカメラなどを活用しユーザビリティテストを行 うことがある。

\section{2 評価の準備}

モニターとなるユーザーの選定は、ユーザビリティ 評価の目的に沿ってユーザ一特性から選定する。ユー 
ザビリティテスティングの場合、何人のモニターでテ ストすれば十分かという議論がよくあるが、狙いの工 ーザーグループが一つであれば典型的なユーザーを 5 人テストすれば、全体の $85 \%$ の問題が発見できるとい うデー夕もある。

テストの準備では、テストの目的を明確にすること はもちろんのことだが、テストの進行シナリオ、タス ク (課題) シナリオ、必要な機材などを用意し、必ず 予備テストを行い、実際のテストに備えることが必要 である。

\section{3 評価の実施}

実際のユーザビリティテスティングでは、評価時間 は 1 時間程度である。評洒目的の説明、発話練習など に始まり、モニターにタスクを与えそれに沿った操作 を行ってもらう。評価においては、モニターの能力や 知識をテストするのが目的ではないので、モニターが 操作に行き詰まったときなどの言動に対する評価進行 者の対応スキルが必要とされる。

\section{4 結果の分析}

評価終了後に、観察者を含めた検討会を行い、問題 点などを整理する。後日、報告書をまとめるにあたつ て、観察メモやテストのビデオなどを分析する。ロギ ングッールを用いて記録したデータを活用することも ある。報告の際には、評価のハイライトビデオを作成 し、実際のテストを観察できなかった関係者によりわ かりやすく説明する。また、問題点をランキングし、 評点に置き換えて報告することもある。

ユーザビリティ評価結果のまとめ方に関しては、米 国に CIF (Commmon Industry Format for Usability
Test Reports）という報告書の ANCI（American National Standards Institute) 規格がある。現状は、 ソフトウエアのユーザビリテイ評価結果を想定した規 格であるが、いずれインタラクティブな製品に関する 規格に発展すると思われる。

\section{4. ユーザビリティ評価における人材育成}

人間中心設計プロセスにおける専門人材は、ユーザ 一の利用状況を把握し要求を分析、抽出するリクワイ アメントエンジニア、設計解決案を検討するユーザビ リティエンジニア、ユーザー要求に沿って解決案を評 価するユーザビリティアセッサーに分類することがで きる。

ユーザビリティ評価を担当するユーザビリティアセ ッサーのコンピテンシーを表 1 に示す。もちろん前提 として、評価対象となる製品に関する基礎的な知識が 必要なことは言うまでもない。また、共通のコンピテ ンシーとしてプロジェクトマネジメント能力、ドキュ メンテーションやプレゼンテーションと言ったコミュ ニケーション能力、企画、分析能力などが必要とされ る。

残念ながら、日本においてはこのような人材の体系 的な有成カリキュラムや資格認定制度がなく、現状で は各企業が実際のユーザビリティ評洒業務を通じて独 自に育成している。なお、ユーザビリティに関する専 門人材の資格認定に関して米国のUPA (Usability Professionals' Association) が一時検討を進めていた が現在は中断している。

\section{5. おわりに}

ユーザビリティ評洒のポイントは、ユーザーの実際

表 1 コンピテンシー表

ユーザビリティアセスメント（UA）コンビテンシー

\begin{tabular}{|c|c|c|c|}
\hline 大項目 & 中項目 & 小項目 & 内容 \\
\hline \multirow{3}{*}{ 評価計 } & \multirow[t]{3}{*}{ 企画・計画能力 } & 評価方法選択能力 & 目的に合った適切な評価の方法を決定できる。 \\
\hline & & 被験者リクルート能力 & ユーザーテストの場合、目的に合った被験者の選択、募集ができる \\
\hline & & $\begin{array}{l}\text { ユーザー要求に基づく } \\
\text { 評価基準の作成能 }\end{array}$ & ユーザー要求に照合しな判断基準を作成し、客観的に評価する能力 \\
\hline \multirow{2}{*}{$\begin{array}{l}\text { 評備実 } \\
\text { 行能力 }\end{array}$} & \multirow[t]{2}{*}{ 評価遂行 } & 手法実践能力 & 手法每の活用・実践できる能力 \\
\hline & & 对人〈被験者〉対応 & 被験者〈ユーザー〉と円滑なコミュニケーションをとり、信頼を得られる \\
\hline \multirow{3}{*}{ 評価分 } & \multirow[t]{2}{*}{ 評価分析能力 } & 問題発見能力 & 問題点と発見の理解〈従来の蓄積デー夕に沿ってメンタルモデル抽出型観察〉 \\
\hline & & 問題分析能力 & 問題の原因の分析 \\
\hline & 結果整理 & 問題整理能力 & 問題点の整理、重み付けを行う \\
\hline \multirow[t]{2}{*}{$\begin{array}{l}\text { 改善提 } \\
\text { 案能力 }\end{array}$} & \multirow[t]{2}{*}{ 改善提案 } & $\begin{array}{l}\text { 改善案〈アイデア〉企 } \\
\text { 画・発想能力 }\end{array}$ & 複数の改善案の創出 \\
\hline & & 改善案整理能力 & 改善案を客観的に判断して実現可能性や重要度から順位付けをする \\
\hline
\end{tabular}


の利用状況の中でいかに機器やシステムをスムーズに 使いこなせるかどうかを評価することにある。したが って、評価の対象となるユーザー特性や、ユーザーの 要求の特定、それらにもとづく評価の課題（タスク） の選定などが重要になる。

ユーザビリティ評価は評価対象となる機器やシステ ムの完成度に左右されることが多いが、できるだけ製 品開発の早い段階、できればコンセプトの段階から評 価を行うことが望まれる。製品開発のステップが進む につれ、問題点の改善において制約が多くなるからで ある。また製品開発のプロセスのなかで、繰り返し評 価を行いユーザビリティをより良いものに練り上げ、 作り込んでいくことが大切である。

デジタル、ネットワークの時代だからこそ使いやす い商品は、ユーザーにとっても、メ一カーにとっても 利益をもたらすという考え方にもとづき、今後さらに ユーザビリティ評価の活動が盛んになっていくと思わ れる。
参考 文 献

[1] 海保博之・原田悦子著,「プロトコル分析入門」, 新曜 社, 1994

[2] ヤコブ・ニールセン著,「ユーザビリティエンジニアリ ング概論」, 東京電機大学出版局, 1999

［3］黒須正明・伊東昌子・時津倫子著，「ユーザ工学入門」, 共立出版，1999

[4] ヒューマンセンタードデザイン小委員会編，「人間中心 設計（ISO13407対応）プロセスハンドブック」，(社）日本 事務機械工業会, 2001

[5] ヒューマンセンタードデザイン小委員会編，「人間中心 設計プロセス実践事例集」，(社）ビジネ・ス機械・情報システ 么産業協会, 2002

［6］黑須正明編著,「ユーザビリティテスティング」, 共立出 版, 2003

[問い合わせ先]

(2004年 2 月 5 日 受付)

干222-8530 神奈川県横浜市港北区新横浜 3-2-3

株式会社リコー 経営品質管理本部 アプライアンス推進室 早川 誠二

TEL : 045-477-1528

FAX : 045-477-1539

E-mail : hayakawa@rdc.ricoh.co.jp

1975年 千葉大学工学部工業意匠学科 卒業。同年 (株) リコー入社。研究企画、 デザイン研究、CI、ドキュメントデザイ ン、ユーザビリティ評価などに従事。91 年 退社。ソニー (株) 入社。ユーザビリ ティ評価、ユーザーインターフェース設 計、ユニバーサルデザインなどに従事。 98年 退社。(株) リコー入社。ユーザビ リティ向_上の全社推進に従事、現在に至 る。ヒューマンインターフェース学会、 日本デザイン学会、日本人間工学会会員。 著書『GUI デザインガイドブック」、『ユー ザビリティテスティング』(いずれも共著) ほか。 